\title{
A KÉNYSZERÍTETT ÖNKISZOLGÁLÁS ELFOGADÁSÁNAK ELŐZMÉNYEI ÉS KÖVETKEZMÉNYEI A BKK-AUTOMATÁK PÉLDÁJÁN KERESZTÜL
}

A mindennapi élet során egyre többször találkozni önkiszolgáló technológiákkal (továbbiakban SST=self-service technology), amelyekkel az ember saját maga végezhet el olyan szolgáltatáselemeket, amelyekhez korábban egy alkalmazott segítségét kellett igénybe vennie. A szolgáltatóvállalatok különböző módon terelhetik fogyasztóikat az új módszer használatának irányába, melynek legradikálisabb megvalósulási formája a kényszerítés, azaz az eredeti kiszolgálási opció elvétele. A szerzők kutatása egy új, empirikus tanulmányokra alapozott elméleti modellt tesztel, melynek középpontjában a kényszerített használattal bevezetett önkiszolgáló technológia elfogadása áll. Az újfajta gondolkodási keret egy valós környezetben vizsgálja ennek előzményeit és következményeit. A kutatás alapjaként szolgálhatott a kényszerített használat teljes megvalósulásának hazai példája, a BKK jegy- és bérletautomaták bevezetése. Ezek a kioszk alapú önkiszolgáló technológiák relatíve hirtelen léptek a pénztárak helyére, kiváltva ezzel a személyes jegyértékesítést. Eredményeik alapján a kényszerített használattal bevezetett önkiszolgáló kioszk elfogadásában az automata észlelt teljesítménye játssza a legnagyobb szerepet, valamint fontos fogyasztói jellemzőként az interakcióra való igény. Mindazonáltal az elfogadási folyamat kulcsfontosságú hatású a vállalathoz fűződő fogyasztói attitűd alakulásában.

\section{Kulcsszavak: önkiszolgáló technológia (SST), kényszerített használat, technológiaelfogadás}

$\mathrm{M}$ indennapi életünk során egyre többször találkozunk önkiszolgáló technológiákkal (továbbiakban SST=self-service technology), amelyekkel magunk végezhetünk el olyan szolgáltatáselemeket, amelyekhez korábban egy alkalmazott segítségét kellett igénybe vennünk. A szolgáltatóvállalatok különböző módokon terelhetik fogyasztóikat az új módszer használatának irányába, melynek legradikálisabb megvalósulási formája a kényszerítés, azaz az eredeti kiszolgálási opció elvétele. Ez a fajta kényszerített használat azonban jelentős fogyasztói ellenérzést válthat ki. Cikkünk központi kérdése, hogy melyek azok a tényezők, amelyek segíthetik a kényszerített használat fogyasztói elfogadását, és ennek kapcsán milyen módon tudja a vállalat támogatni az önkiszolgáló technológia bevezetését. Kutatásunk középpontjában a kényszerített használattal bevezetett önkiszolgáló technológiákkal szembeni fogyasztói attitűd áll, mely témakört ez idáig nem vizsgálta a hazai szakirodalom. Nemzetközi viszonylatban is figyelemreméltó tény, hogy kutatásunkban a kényszerített használat nem egy hipotetikus szituációként kerül a tanulmány középpontjába, hanem valós esetre adott fogyasztói reakciókat vizsgálunk. Kutatásunk ötvözi az SST-szakirodalomban használt modellek különböző aspektusait, új megvilágításba helyezve a kényszerített használat bevezetésének jelentőségét. Cikkünk első fejezetében tisztázzuk a kényszerített önkiszolgálás fogalmát, a kutatási terület szakirodalmi hátterét. Bemutatjuk helyét a vállalatok által alkalmazott önkiszolgáló technológiák fogyasztói használatát ösztönző eszközrendszerben, majd bevezetésük előzményeit és következményeit vizsgáljuk. Ezt követően ismertetjük hipotéziseinket, melyeket elméleti modellünkön végighaladva veszünk sorba. Hat hipotézisünkkel lefedjük a kényszerített elfogadást középpontjába foglaló modell kapcsolatrendszerét, mely elözményváltozóként technológiai és fogyasztói jellemzőket, következményként pedig a vállalat iránti attitüdöt vonultatja fel. A kutatásunk módszertanát összefoglaló fejezetben bevezetjük a hazai kutatás alap- jaként szolgáló BKK-automaták kontextusát, majd empirikus eredményeinket összegezzük. Végül értékeljük ezeket, folyamatosan visszacsatolva a korábbi szakirodalmi eredményekhez. Cikkünket következtetéseinkkel zárjuk, melyben munkánk elméleti és gyakorlati jelentőségének hangsúlyozásán túl megfogalmazzuk kutatásunk korlátait, valamint lehetséges jövőbeli kutatási irányokat vázolunk föl.

\section{Elméleti háttér: a kényszerített önkiszolgálás}

Az önkiszolgáló rendszerek segítségével a vállalatok a kereskedelemben és a különböző szolgáltatások esetében is bizonyos feladatkörök elvégzését helyezik a fogyasztók hatáskörébe. A kezdetben költségcsökkentő célzattal indult felhasználásuk azonban további előnyöket jelent mind a vállalatok, mind pedig a fogyasztók részére. Ez az optimális esetben win-win szituáció csak akkor jöhet létre, ha sikeresen vezetik be az adott technológiát, amit aztán használnak is a fogyasztók (Keszey - Zsukk, 2017; Kenesei - Janecskó, 2015).

A szolgáltatóvállalatok leggyakrabban pozitív vagy negatív ösztönzőkkel terelik a fogyasztókat az önkiszolgáló technológiák használata felé (Liljander és szerzőtársai, 2006). Pozitív ösztönzőnek, egyfajta jutalmazó stratégiának számítanak a különböző kedvezmények, egyedi ajánlatok, negatívnak pedig az eredeti opció kedvezőtlenné tételét célzó használati díjak, büntetés kiszabása. Legradikálisabb esetben pedig elveszik a hagyományos szolgáltatási alternatíva lehetőségét, amelyet egyébként kezdetben az adott önkiszolgáló technológia csak opcionálisan váltott ki; ezt nevezzük kényszerített használatnak (Reinders és szerzőtársai, 2008). Trampe és szerzőtársai (2014) alapján a jutalmazó stratégia sokkal hatásosabb a büntetőnél, utóbbi módszer pedig ugyanakkora ellenállást vált ki, mint önmagában a kényszerítés. Belátható tehát, hogy a bevezetési stratégiák közötti választás kellő körültekintést igényel. Alapvetően az egyes vállalatok a kényszerített használat alkal- 
mazása mellett az adott SST gyorsabb bevezetése céljából, és a hatékonysági előnyök mielőbbi kiaknázása érdekében döntenek. A kényszerítés azonban teljes mértékben átformálhatja, negatívan befolyásolhatja adott SST fogyasztói elfogadását.

Ennek magyarázata alapvetően két pszichológiai elméletre vezethető vissza, a döntési kontroll és a pszichológiai ellenállás elméletére. Előbbi lényege, hogy a fogyasztók döntési szabadságukban elszenvedett sérelmük miatt döntési kontrolljuk is csökken, ami negatívan hat az önkiszolgáló technológia értékelésére (Reinders és szerzőtársai, 2008). Utóbbi elmélet szerint, ha a fogyasztókat kényszerítik egy alternatíva használatára, az automatikusan ellenkezést, negatív érzéseket válthat ki belölük a technológia irányába, hiába vannak tudatában a használat előnyeinek (Johnson és szerzőtársai, 2008).

A fogyasztói elfogadás első lépéseként a kényszerített használattal bevezetett SST kipróbálásáig vezető utat az elégedettségen át vizsgálta Liu 2012-es kutatásában. A kényszerített használat háromféle útvonalon befolyásolhatja az elégedettségen keresztül a használati szándékot. Egyfelöl növeli a technológiai szorongást (egyfajta félelem, nyugtalanság, amit a fogyasztók éreznek egy új technológia használatának megfontolása vagy konkrét alkalmazása során (Meuter és szerzőtársai, 2003), ami viszont negatívan hat az elégedettségen át a használati szándékra. Másfelől csökkenti a technológiai bizalmat (Johnson (2007) alapján a fogyasztói várakozás a megfelelő és megbízható teljesítményre), mely ugyanakkor pozitív hatással van az elégedettségre és a használatra. Végül a kényszerített használat által megnövekedett technológiai szorongás csökkenti a technológiai bizalmat, amely az elégedettségen keresztül növeli a használati szándékot.

A kényszerített használat szakirodalmában kiemelt hangsúlyt kap következményeinek vizsgálata. Az SST ráerőltetése a fogyasztókra akár a teljes vállalat szolgáltatásának észlelt minőségét is ronthatja (Lin - Hsieh, 2006). Ezen túlmenő következményeket vizsgáltak Reinders és szerzőtársai 2008ban, amikor is egy hipotetikus vonatjegyvásárlás példáján keresztül végezték kutatásukat, melyben szcenárióként szerepelt a fogyasztók számára az SST kötelező alkalmazása. Kimutatták, hogy a kényszerített használat nem csupán az igénybevétel, hanem a szolgáltató iránti attitüdöt is negatív irányba befolyásolja, melynek hatására a szájreklám lehetősége is csökken, és növekszik az utazási mód váltására irányuló szándék.

A negatív következményeket látva bizonyos, hogy az önkiszolgáló technológiák fogyasztókra való ráerőltetése komolyabb megfontolást kíván a vállalatok részéről. Scherer és szerzőtársai (2015) például egyenesen azt javasolják, hogy nem szabad a vevőket kizárólag egy vagy több SST irányába terelni (legfóképp az adott szolgáltatóval való kapcsolat kialakításakor), mert az negatívan befolyásolja a vevőmegtartást. A fogyasztói és vállalati előnyök legmagasabb szintü kiaknázása érdekében az önkiszolgáló rendszerek mellett a hagyományos alternatíva optimális fokú megtartását is szükségesnek tartják, mindez bizonyos iparágak esetén (például hotelszektor) hatványozottabban igaz (Oh és szerzőtársai, 2013; Kokkinou - Cranage, 2013). Ha azonban túllépünk a kezdeti ellenálláson, és a fogyasztók már hozzászoktak ahhoz, hogy bizonyos szolgáltatáselemeket csak önkiszolgáló technológiák alkalmazásával vehetnek igénybe, akkor gyakran belátják annak előnyeit rájuk nézve (Kelly és szerzőtársai, 2013).
Összefoglalva a kényszerített használat témakörében fókuszáltan annak következményeit, stratégiáit, módszereit kutatták, általában szcenárióelemzéssel, tehát a konkrét kényszerítés gyakran csak fiktív formában volt jelen, nem pedig egy valós kontextusban. Kivételt képez ez alól többek közt Reinders és szerzőtársai 2008-as holland vasúti közlekedést alapul vevő és Reinders és szerzőtársai 2015-ben a holland tömegközlekedésben bevezetett chip kártyát felhasználó kutatása. A kényszerített használat fogyasztói elfogadásának jelen cikkben bemutatott kutatása ötvözi az SST kutatásában használt modellek különböző aspektusait, új megvilágításba helyezve a kényszerített használat bevezetésének jelentőségét.

\section{Hipotézisek}

A szakirodalmi empirikus kutatásokat alapul véve alakítottuk ki elméleti modellünket, melyben a kényszerített használat elfogadása állt a középpontban. Hozzá kapcsolódóan öt befolyásoló tényező hatását vizsgáltuk, melyek fogyasztói és technológia jellemzőket egyaránt tartalmaztak. Továbbá a kényszerített használat elfogadásának következményeként elemeztük a vállalattal szembeni elégedettséget egyaránt. A modell alapján az említett kapcsolatok vizsgálatára összesen hat hipotézist fogalmaztunk meg, amelyek első része a fogyasztók jellemzőinek hatását, míg második csoportja a technika jellemzőinek hatását mutatja be (1. ábra).

\section{Fogyasztói jellemzők: interakcióra való igény}

Az interakcióra való igényt Dabholkar 1996-ban a fogyasztók szolgáltatási folyamat során fellépő emberi kontaktusra való szükségleteként írta le. Fontos meghatározó tényező adott SST elfogadásában, ugyanis minél magasabb az értéke, annál inkább akadályozza az elfogadási folyamatot (Curran - Meuter, 2005; Walker - Johnson, 2006). Hatását legtöbbször független vagy moderáló változóként kezelik (Dabholkar - Bagozzi, 2002), de mediáló változóként is találunk rá példát. Utóbbit példázzák Oh és szerzőtársai (2013) kutatásukban, ahol az is kiderül, hogy vannak olyan fogyasztók, akik esetében az interakció iránti igény a szállodai kontextusban nem írható fölül, erőssége pedig annak függvényében változhat, hogy épp milyen tranzakciót kell végrehajtaniuk. A kényszerített használat elfogadása esetén valószínüsíthető, hogy ha valakinél magas az interakcióra való igény, akkor nehezebben fogad el egy kényszerített használattal bevezetett önkiszolgáló kioszkot.

\section{H1. Az interkacióra való igény növekedésével csökken a kényszerített használat fogyasztói elfogadása.}

\section{Fogyasztói jellemzők: szociális szorongás}

A szociális szorongás jellemzően a szakirodalomban a sorbanálláson, mint szituációs tényezőn keresztül megvalósuló moderáló faktor, mely megléte esetén akadályozza adott SST elfogadását (Dabholkar - Bagozzi, 2002; Gelbrich - Sattler, 2014). A tömeg ugyanis egyfajta diszkomfort érzetet generálhat a fogyasztókban (Fenigstein és szerzötársai, 1975), kialakítva a szociális szorongás érzetét (Langer - Saegert, 1977; Hui - Bateson, 1991), ami hátráltató tényező egy új technológia kipróbálása esetén. Ezzel szemben kutatásunkban fogyasztói jellemzőként kezeljük, mivel segítségével különbség 
tehető a tömeget jobban vagy kevésbé elviselő személyek magatartásában. Egy önkiszolgáló automata esetében megjelenhet stresszfaktorként önmagában a sor, továbbá zavaró lehet a tudat, hogy mit gondolnak a használóról a mögötte állók, ha az egyén esetleg elront valamit vagy hosszabb ideig áll a kioszk előtt. Az így kapott tényező hasonló, de nem összekeverendő a máshol használt önkép vagy öntudatosság tényezővel, amely azt fejezi ki, hogy az emberek mennyire érzékenyek a körülöttük lévők véleményére. Utóbbi szociális kockázatként negatívan befolyásolhatja egy önkiszolgáló technológia kipróbálásával szembeni attitűdöt (De Ruyter és szerzőtársai, 2001). Feltételezésünk alapján minél inkább érzékeny valaki a körülötte lévő tömegre, annál nehezebben fogadja el a kényszerített használattal való bevezetést.

\section{H2. A szociális szorongás növekedésével csökken a kényszerített használat fogyasztói elfogadása.}

\section{Fogyasztói jellemzők: önhatékonyság}

Az önhatékonyság a fogyasztó saját értékelése arra vonatkozóan, hogy mennyire magabiztos adott technológiák sikeres alkalmazásában (Bandura, 1977, 1994). A tényező visszavezethető a szerző szociális kognitív elméletére, miszerint az önhatékonysággal kapcsolatos hiedelmeink kulcsmeghatározói konkrét viselkedésünknek. Egy új SST kipróbálása nyilvánvalóan a megfelelő készségek mellett megfelelő önbizalmat is igényel a kipróbálóktól (Limayem és szerzőtársai, 2007), magasabb értéke esetén támogatja az elfogadást (Zhao és szerzőtársai, 2008; Van Beuningen és szerzőtársai, 2009). Modellünkben hasonlóképpen gondolkodva megállapítható, hogy minél biztosabb valaki abban, hogy könnyedén tud kezelni egy önkiszolgáló automatát, annál valószínűbben fogadja el azt önmagában, valamint szélsőséges esetben annak kötelező használatát egyaránt.

\section{H3. Az önhatékonyság növekedésével emelkedik a kényszerített használat fogyasztói elfogadása.}

\section{Technológiai jellemzők: használati könnyűség}

Átlépve a technológiai jellemzők körébe fontos kiemelni, hogy itt minden esetben a fogyasztók által szubjektív módon észlelt tényezőkről beszélünk. A használati könnyűség annak a mértékét fejezi ki, hogy a fogyasztók elvárásai szerint egy konkrét technológia használata mekkora erőfeszítést jelent számukra (Davis és szerzőtársai, 1989). A tényező a TAM-modell (technológia elfogadás modelljének) egyik alapja, mely konstrukció az átgondolt cselekvés elméletére épül (Ajzen - Fischbein, 1980). Minél egyszerübbnek érzékelik a fogyasztók egy adott technológia használatát, annál könnyebben fogadják el azt (Davis és szerzőtársai, 1989). Az SST elfogadásával kapcsolatos tanulmányok túlnyomó többségének alapja a TAM-modell; Blut és szerzőtársai (2016) metaanalízisükben egyenesen azt javasolták, hogy a TAM-ban használt két alaptényezőnek (használati könnyűségnek és hasznosság- nak) minden SST-kutatásban szerepelniük kell. Mindezek alapján, ha egy önkiszolgáló kioszk kezelését könnyűnek érzékelik a fogyasztók, úgy valószínübb, hogy könnyebben elfogadják annak bevezetését, még ha az kényszerített módon történt is.

H4. Az észlelt használati könnyüség növekedésével emelkedik a kényszerített használat fogyasztói elfogadása.

\section{Technológiai jellemzők: teljesítmény}

A TAM-modell másik meghatározó alaptényezője, az észlelt hasznosság helyett alkalmazott faktorunk, Dabholkar (1994) alapján az észlelt teljesítmény. Az önkiszolgáló technológiák elfogadásával foglalkozó tanulmányokban gyakran találkozhatunk az észlelt hasznosság elemzésével (Curran - Meuter, 2005; Lin és szerzőtársai, 2007), mely bár hasonló módon ragadja meg egy innováció észlelt müködőképességét, mégis ragaszkodunk a Dabholkar által javasolt teljesítmény megnevezéshez. A szerző szerint ugyanis a teljesítmény magába foglalja az új technológia fogyasztó által észlelt megbízhatóságát és pontosságát. Azok számára, akik egy SST esetén magasra értékelik annak teljesítményét, pozitívabb attitüddel viseltetnek majd iránta, támogatva annak tényleges használatát (Dabholkar - Bagozzi, 2002). Ezek alapján feltételezzük, hogy minél magasabb egy önkiszolgáló automata észlelt teljesítménye, annál könnyebben valósulhat meg kényszerített bevezetésük elfogadása.

\section{H5. Az észlelt teljesítmény növekedésével emelkedik a kényszerített használat fogyasztói elfogadása.}

\section{A szolgáltatóval szembeni attitűd}

Kutatások alapján a kényszerített használattal bevezetett önkiszolgáló technológiák egyik legveszélyesebb következménye, hogy a negatív szájreklám és a negatív tapasztalatok miatt romlik a vállalat megítélése, egyúttal növekszik az elpártolás (Reinders és szerzőtársai, 2008). Mindez azért történhet meg, mivel a fogyasztók gyakran emocionálisan kötődnek az általuk megszokott kiszolgálási formához (Bitner és szerzőtársai, 2002), ha pedig kényszerítve érzik magukat egy új módszer kipróbálására, az mindenképpen negatív következményeket von maga után. Éppen ezért, ha egy szolgáltatóvállalatnak különböző módszerekkel sikerül elérnie, hogy a fogyasztói mégis elfogadják az új önkiszolgáló rendszert a kényszerítés ellenére, úgy az pozitívan hathat a vállalat megítélésére egyaránt.

H6. Minél kevésbé hajlandó a fogyasztó a kényszerített használatot elfogadni, annál negatívabb képet alakít ki a vállalatról. 
A vizsgált elméleti modell

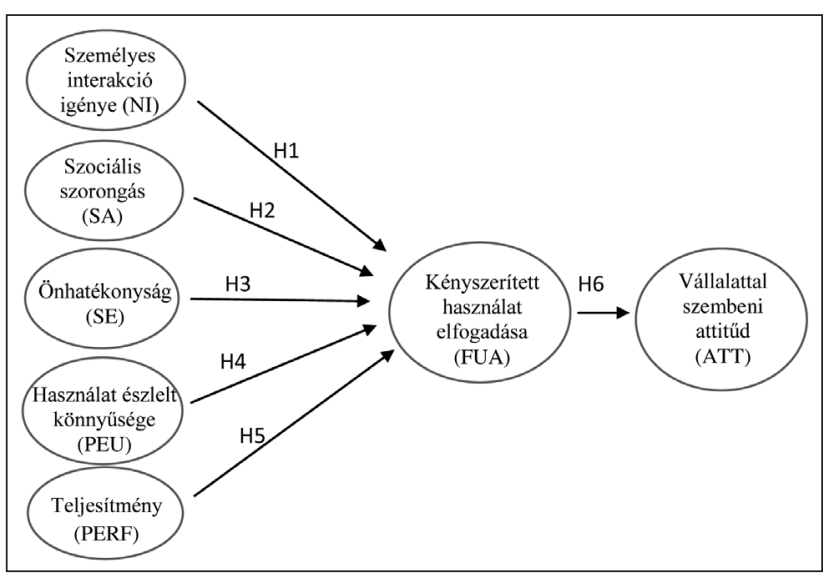

\section{A kutatás módszertana}

Empirikus vizsgálatunk középpontjába a BKK jegy- és bérletvásárlásra alkalmas automatáit helyeztük, mivel ez a kioszk alapú önkiszolgáló technológia relatíve hirtelen lépett a pénztárak helyére, amelyhez a fogyasztók évtizedeken át hozzászoktak és ragaszkodtak. A BKK 2014 tavaszán helyezte üzembe Budapesten az első jegyárusító automatákat, melyek rövid ideig müködtek párhuzamosan az eredeti kiszolgálási formával, majd hozzávetőlegesen fél évvel később minimálisra csökkentették a személyes kiszolgálási lehetőségek számát. Ma már csak néhány forgalmas közlekedési csomópontban vásárolhatnak a fogyasztók jegyet és bérletet pénztárnál vagy ügyfélközpontokban. Mindez ideális környezetet teremtett a kényszerített használat elözményeinek és következményeinek vizsgálatára.

Módszerként online kérdöíves megkérdezést alkalmaztunk, mely kérdöívet összesen 198 személy töltött ki, mintavételünk nem tekinthető reprezentatívnak. Érvényes válaszadóknak azonban csak a 18 és 65 év közötti (Magyarországon a jelenlegi nyugdíjkorhatárt jelentő 65 év felett ingyenes a tömegközlekedés), a BKK-automatát már legalább egyszer használó fogyasztókat ítéltük, így a végleges mintanagyság 176 före csökkent. Mintánk demográfiai jellemzőit tekintve megfigyelhető volt a nők dominanciája 80,7\%-kal (feltétele- zésünk szerint ez visszavezethető a közlekedési bérletek megvásárlásában betöltött domináns szerepükre a családban). A kitöltők életkorának átlaga 36 év, a legfiatalabb kitöltő 18, míg a legidősebb 65 éves volt.

Az elméleti modellünket alkotó tényezők mérésére ötpontos Likert-skálákat alkalmaztunk. Az előzményváltozók közül az interakcióra való igény számszerüsítésére Dabholkar (1996) három elemű skáláját használtuk fel, míg a szociális szorongást megtestesítő háromelemű skála megfogalmazásakor Gelbrich és Sattler (2014) munkáját vettük alapul. Az önhatékonyságra vonatkozó három elem Webster és Martocchio (1992) munkájából származtatható. Áttérve a technológiai jellemzökre, az észlelt használati könnyüséget és teljesítményt egyaránt 3-3 elemű skálákon mértük a kérdőívben, Dabholkar (1994) alapján. A következményként kezelt szolgáltatóval szembeni attitüd háromelemű skáláját Reinders és szerzőtársai (2008) munkája alapján fogalmaztuk meg. Végül a modell középpontjában álló kényszerített használat elfogadásának számszerüsítésére ötelemü skálát alakítottunk ki, mely egyfajta attitűdváltozóként ragadta meg a kényszerített használattal bevezetett önkiszolgáló kioszkkal szembeni beállítottságot (Davis és szerzőtársai, 1989).

\section{Eredmények}

A modell tesztelése során Anderson és Gerbing (1988) kétfázisú eljárását alkalmaztuk. Először konfirmatív faktorelemzéssel megvizsgáltuk a mérési modell megfelelését, majd strukturális egyenletek (SEM) segítségével teszteltük magát a modellt ${ }^{1}$.

Az első fázisban a kompozit mérőeszközök belső koherenciája koherenciáját és megbízhatóságát teszteltük. A konfirmatív faktorelemzés eredményeként elmondhatjuk, hogy a faktorsúlyok minden esetben magasabbak 0,6-nél, és a Cronbach Alfa értékeke 0,77 és 0,91 közötti értéket adnak (1. táblázat). A skálák kompozit megbízhatósága (CR-Composit Reliability) minden esetben 0,7 fölötti értéket mutatnak. Az AVE (Average Variance Extracted) érték 0,5 fölötti (Bagozzi - Yi, 1988), ami szintén az erős belső kohéziót mutat. Az egyes mérőeszközök közötti diszkrimináns megbízhatóságot Fornell és Larcker (1981) javaslata alapján az AVE-értékek négyzetgyökének a skálák egymás közötti korrelációjához való viszonyával mértük. A skálák közötti korreláció mértéke egyik esetben

A megbízhatóság és érvényesség vizsgálata

\begin{tabular}{|l|l|l|l|l|l|l|l|l|l|l|}
\hline & Cr. $\boldsymbol{\alpha}$ & CR & AVE & FUA & PEU & SE & SA & ATT & PERF & NI \\
\hline FUA & 0.91 & 0.90 & 0.66 & $\mathbf{0 . 8 1}$ & & & & & & \\
\hline PEU & 0.82 & 0.82 & 0.61 & 0.65 & $\mathbf{0 . 7 8}$ & & & & & \\
\hline SE & 0.81 & 0.80 & 0.58 & 0.51 & 0.65 & $\mathbf{0 . 7 6}$ & & & & \\
\hline SA & 0.77 & 0.78 & 0.54 & -0.28 & -0.40 & -0.42 & $\mathbf{0 . 7 4}$ & & & \\
\hline ATT & 0.87 & 0.87 & 0.69 & 0.67 & 0.48 & 0.27 & -0.20 & $\mathbf{0 . 8 3}$ & & \\
\hline PERF & 0.80 & 0.80 & 0.58 & 0.68 & 0.62 & 0.33 & -0.27 & 0.52 & $\mathbf{0 . 7 6}$ & \\
\hline NI & 0.86 & 0.85 & 0.67 & -0.63 & -0.47 & -0.48 & 0.29 & -0.26 & -0.29 & $\mathbf{0 . 8 1}$ \\
\hline
\end{tabular}

$\mathrm{CR}=$ composite reliability, $\mathrm{AVE}=$ average variance extracted, Korrelációs mátrix (a diagonálison az AVE érték négyzetgyöke szerepel) 
sem haladta meg a skálák AVE-értékének a négyzetgyökét. A konfirmatív faktorelemzés során a modell kellőképpen illeszkedett $(\chi 2(206)=353 ; \chi 2 / \mathrm{df}=1,72, \mathrm{p}<0.001 ; \mathrm{RMSEA}=0.061$; $\mathrm{CFI}=0.94, \mathrm{IFI}=0.92, \mathrm{TLI}=0.92)$. sának hatását kívánta tesztelni a szolgáltató, jelen esetben a BKK-val szembeni attitűdre. Ez a hipotézisünk is beigazolódott, annakazt, hogy egy fogyasztó mennyire fogadta el a rákényszerített opciót jelentősen befolyásolta a BKK-ról alkotott képét $(\beta=0.67)$.

2. táblázat

\section{A „Kényszerített használat elfogadása” skála jellemzői}

\begin{tabular}{|l|l|}
\hline Skálaelemek & Faktorsúlyok \\
\hline Örülök annak, hogy automatából vehetek jegyet vagy bérletet a pénztárak helyett. & 0.88 \\
\hline Véleményem szerint jó ötlet volt a BKK-jegypénztárak automatákra cserélése. & 0.86 \\
\hline Jobban szeretek BKK-automatából jegyet vagy bérletet venni, mint pénztárnál. & 0.78 \\
\hline Ha jegyet vagy bérletet kell vennem, dühít, hogy sokszor csak BKK-automatát tudok használni. & -0.75 \\
\hline $\begin{array}{l}\text { Számomra elfogadható, hogy sokszor csak BKK-automatát tudok használni, ha jegyet vagy bérletet } \\
\text { szeretnék vásárolni. }\end{array}$ & 0.78 \\
\hline
\end{tabular}

Az egyes skálák közül a kényszerített használattal szembeni attitüd skáláját mutatjuk be, tekintettel arra, hogy ez egy saját fejlesztésű skála (2. táblázat).

A modell tesztelésére a SEM-módszert használtuk az SPSS AMOS 20.0 szoftver segítségével. A módszer lehetővé teszi, hogy a modellben feltételezett kapcsolatokat szimultán teszteljük. A modell illeszkedése megfelelönek tekinthetö (3. táblázat). A strukturális egyenletek tesztelése során két hipotézist elvetettünk, míg négyet elfogadtunk. H1 hipotézisünk megállta a helyét $(\beta=-0.33)$, így elmondhatjuk, hogy a fogyasztók interakcióra való igénye negatívan befolyásolja, hogy mennyire fogadták el a kényszerített használatot. H2 hipotézisünket elvetettük ( $(=0.03$ ), így nem erösítettük meg azt az előzetese feltételezésünket, hogy a szociális szorongás csökkenti a kényszerített használat elfogadását. Hasonlóképpen a H3-ban megfogalmazott állítást, amely szerint az önhatékonyság növekedésével növekszik az elfogadás, szintén el kellet utasítanunk $(\beta=0.07)$. Ellentétben az előzőekkel a hagyományos TAM-változók, mint a használat észlelt könynyűsége és az észlelt hatékonyság erősítették az elfogadást, így mind a H4-et $(ß=0.19)$, mind a H5-öt $(\beta=0.67)$ elfogadtuk.

\section{Az eredmények értékelése}

Habár manapság divatos és rengeteg vállalati megtakarítással jár az önkiszolgáló technológiák alkalmazása, bevezetésük mégis kellő körültekintést igényel. Hiába csábító a gazdasági előnyök mielőbbi kiaknázása érdekében a gyorsabb bevezetés reményében elvenni az eredeti személyes kiszolgálási alternatívát a fogyasztóktól, az gyakran ellenkezést vált ki bennük. Empirikus kutatásunk megerősíti a korábbi tanulmányok eredményeit a fogyasztók új kiszolgálási forma használatára való kényszerítésének negatív következményeiről (Liu, 2012; Reinders és szerzőtársai, 2008). Eredményeinkből kiderült, hogy a technológia jellemzőinek - az észlelt használati könnyűségnek és a teljesítménynek - kulcsfontosságú a szerepe, esetünkben akkor is, ha csak az önkiszolgáló kioszk áll rendelkezésre a fogyasztók számára a személyes kiszolgálás lehetősége nélkül. Mindez összhangban van a két tényező SST-irodalomban megjelenő hatásával (Blut és szerzőtársai, 2016).

Habár a technológia jellemzői szignifikánsnak mutatkoztak, ugyanez nem mondható el a vizsgált fogyasztói tényezők mindegyikéről. Érdekes módon a fogyasztói jellemzők közül csak az interakcióra való igény bizonyult fontosnak a kényszerített használat elfogadásában. Ez összhangban van a

3. táblázat

Hipotézistesztelés eredménye

\begin{tabular}{|l|l|l|}
\hline Feltételezett hatás & Standardizált regressziós együttható & Eredmény \\
\hline Személyes interakció igénye => Kényszerített használat elfogadása & $-0.33 * *$ & H1 elfogadva \\
\hline Szociális szorongás => Kényszerített használat elfogadása & $0.03 \mathrm{nsz}$ & H2 elutasítva \\
\hline $\begin{array}{l}\text { Önhatékonyság } \\
\Rightarrow>\text { Kényszerített használat elfogadása }\end{array}$ & $0.07 \mathrm{nsz}$ & H3 elutasítva \\
\hline Használat észlelt könnyűsége => Kényszerített használat elfogadása & $0.19^{*}$ & H4 elfogadva \\
\hline Teljesítmény => Kényszerített használat elfogadása & $0.47 * *$ & H5 elfogadva \\
\hline $\begin{array}{l}\text { Kényszerített használat elfogadása } \\
\Rightarrow \text { BKK-val szembeni attitűd }\end{array}$ & $0.67 * *$ & H6 elfogadva \\
\hline$* p<0,05 ; * * p<0,01 ;$ n.sz.- nem szignifikáns & \\
\hline Modellilleszkedés: $(\chi 2(213)=384.7 ; \chi 2 / d f=1,81, p<0.001 ;$ RMSEA $=0.068 ;$ CFI $=0.92$, IFI $=0.93$, TLI $=0.91$ & \\
\hline
\end{tabular}


rint megléte erőteljesen akadályozza az önkiszolgáló eszközök felé való nyitást a fogyasztók részéről (Dabholkar, 1996; Curran - Meuter, 2005). Hiába vizsgáltuk az SST nyilvános területen elhelyezett kioszk volta miatt megalapozottnak tűnő szociális szorongás és önhatékonyság változókat (Dabholkar - Bagozzi, 2002; Gelbrich - Sattler, 2014), esetünkben egyik sem bizonyult szignifikánsnak.

Tehát BKK-automata esetében empirikusan nem igazolható, hogy az embereket feszélyezi a mögöttük sorban állók jelenléte. Ennek oka lehet, hogy egy olyan begyakorolt vásárlási folyamatról beszélünk, amit már magabiztosan végeznek a fogyasztók, tehát amennyiben kialakul is sor az automaták előtt, úgy az kivárhatóvá válik. Mindezt magyarázhatja az automaták számának optimális mérete és elhelyezkedésük sürüsége is, tehát az utazóknak számos lehetőségük van jegyük és bérletük megváltására, ami előnyként is funkcionál a személyes kiszolgálási formához képest. Önhatékonyságban az előző tényezővel összhangban elképzelhető, hogy eltünt a különbség a fogyasztók között önhatékonyságuk értékelésében, mivel már hozzászoktak az önkiszolgáló technológiák használatához. Eljutunk tehát oda, hogy már generációs különbségek sem lelhetők fel ebből a szempontból; az idősebbnek számító korosztály is könnyedén megbirkózik a feladattal. Érdekes tehát, hogy az újabb és újabb önkiszolgálási formák bevezetése automatikusan együtt erősíti az önhatékonyságot, így az nem játszik szerepet a kényszerített használatú bevezetés elfogadásában sem.

\section{Következtetések}

Kutatásunk elméleti és gyakorlati jelentősége egyaránt meghatározó. Ugyanakkor a gyakorlati, esetünkben menedzseri következtetések túlsúlyba kerülhetnek; eredményeink alapján ugyanis javaslatok tehetők azon vállalatok számára, melyek egy önkiszolgáló technológia bevezetését fontolgatják. Ha egy vállalat a kényszerítés stratégiája mellett dönt, úgy a következőkben olyan aspektusokra hívjuk fel a figyelmet, amelyek támogathatják ennek elfogadási folyamatát. A technológiai jellemzők közül amennyiben a rendszer könynyen kezelhető, úgy sokkal inkább elfogadják használatukat a fogyasztók, és nem lép fel náluk a kényszerítés miatti ellenkezés, negatív attitüd. Mindez fontos szempont a kötelező használattal bevezetni kívánt technológiák tervezésekor. Az észlelt teljesítmény hatása még erősebbnek bizonyult a BKKautomata esetében. Utóbbi tényezőhöz hasonlóan egy önkiszolgáló kioszk észlelt teljesítménye is egy operatív szempont, melyet tervezéskor kell előtérbe helyezni, valamint karbantartással, az automata szoftverének fejlesztésével, a felmerülő hibák folyamatos javításával kell szinten tartani és növelni észlelt értékét a fogyasztók fejében.

A fogyasztói jellemzők közül az interakcióra való igény mutatott szignifikáns negatív kapcsolatot a kényszerített használat elfogadásával. Mindez igazolja, hogy megtalálható egy olyan szegmens a mintában, akik számára még a közlekedési jegy- és bérletvásárlás során is fontos az emberi kontaktus. A gyakorlatban ezen szegmens felmérése fontos feladata az önkiszolgáló technológiát bevezetni kívánó cégek számára, továbbá célszerü alkalmazkodniuk a problémához a személyes kiszolgálás opciójának minimális fokú megtartásával. Ugyanez történhetett a BKK esetében is, mikor kialakították az ügyfélközpontok rendszerét. Kiderült, hogy a modell legerösebb kapcsolata a kényszerített használat elfogadása és a vállalattal való elégedettség között van. Ha tehát sikerül elérni, hogy a fogyasztók elfogadják a kényszerített használatú bevezetést, akkor növekszik elégedettségük a vállalat iránt. A BKK esetében az automata és egyéb hasznos innovációk erőteljesen pozitív irányba befolyásolhatják a fogyasztók vállalattal való elégedettségét. Ezért is fontos szempont a kényszerítés elfogadtatása a felhasználókkal.

Elméleti szempontból hazai viszonylatban újszerü témával foglalkoztunk; így a kényszerített önkiszolgálás elfogadásának elmélete csatlakozhat azon magyar nyelvü szakcikkhez, melyek a technológiaelfogadást vizsgálják bizonyos aspektusokból hazai környezetben (Keszey - Zsukk, 2017; Kenesei - Janecskó, 2015). Mindemellett a nemzetközi szakirodalomban sikerült felsorakozni azon ritka kutatásokhoz, melyek valós környezetben tudták vizsgálni egy kényszerített módon bevezetett önkiszolgáló technológia fogyasztói elfogadását. Továbbá felmerültek olyan új aspektusok is, melyek elörevetíthetik az SST-irodalom átalakulását; bizonyos tényezők (például az önhatékonyság, demográfiai jellemzőként az életkor) befolyásoló hatása megszűnhet általánosságban a technológiai újításokhoz, specifikusan az önkiszolgáló technológiákhoz való folyamatos alkalmazkodás révén.

Mindazonáltal szót kell ejtenünk kutatásunk korlátairól és lehetséges hibáiról. A kérdőív online terjesztése vethet fel problémákat, de a minta alapvetően jól bemutatta a különböző életkorú kitöltők véleményét. Az eredmények valamelyest módosulhattak volna, ha a számítógépet kevésbé használó személyek is kitölthették volna a kérdöívet, ennek hatása feltételezhetően az önhatékonyság értékelésében mutatkozhatott volna meg. Az internetpenetráció problémaköre nem jelent meg esetünkben, mivel a téma miatt föként a budapesti lakosság képezte kutatásunk célcsoportját. Lehetséges továbbá, hogy léteznek olyan más kényszerített használat elfogadását befolyásoló tényezők, amelyeket nem tudtunk megjeleníteni a kutatásban. Érdekes aspektus továbbá, hogy a BKK-automaták kényszerített használata három éve kezdődött, így valószínü, hogy a kezdeti ellenkezést a megszokás és a beletörödés az idő múlásával megtörte. Ráadásul árnyalta a kényszerítést az ügyfélközpontok bevezetése is.

Az önkiszolgáló technológiák kutatásának jövőbeli irányai között vizsgálandó a fogyasztói jellemzők jelentőségének átalakulása. Magyarországon az újabb önkiszolgáló automaták bevezetése nyújthat alapot az elméleti tézisek, új változók, következmények vagy szituációs tényezők tesztelésére, mint például a McDonald's új rendelésfelvevő kioszkjai vagy a Tesco önkiszolgáló kasszával összekötött vonalkód-leolvasó rendszere. Folyamatosan teret hódítanak továbbá az okostelefonos applikációk, amelyek érdekes módon remek segítséget nyújthatnak az idősebb korosztály számára is, akikről korábban azt gondoltuk, ódzkodnak a technológiahasználattól. Fontos és dinamikusan fejlődő kutatási irányt jelenthet konkrétan a kioszkok és a mobilapplikációk térnyerésének iparágspecifikus vizsgálata, ami akár egymás kárára vagy egymást erösítve is történhet.

\section{Jegyzetek}

${ }^{1} \mathrm{Az}$ alkalmazott módszer és az indexek leírása részletesen megtalálható (Keszey, 2018) cikkében. 


\section{Felhasznált irodalom}

Ajzen, I. - Fishbein, M. (1980): Understanding Attitudes and Predicting Social Behavior. Englewood Cliffs, NJ: Prentice Hall

Bandura, A. (1977): Self-Efficacy: Toward a Unifying Theory of Behavioral Change. Psychological Review, 84, p. 191-215.

Bandura, A. (1994): Self-Efficacy: The Experience of Control. New York: Freeman

Bitner, M. J. - Ostrom, A - Meuter, M. (2002): Implementing Successful Self-Service Technologies. Academy of Management Executive, 16 (4), p. 96-108.

Blut, M. - Wang, C. - Schoefer, K. (2016): Factors influencing the acceptance of self-service technologies: A meta-analysis. Journal of Service Research, 19(4), p. 396-416.

Curran, J. M. - Meuter, M. L. (2005): Self-Service Technology Adoption: Comparing Three Technologies. Journal of Services Marketing, 19 (2), p. 103-113.

Dabholkar, P. A. (1994): Incorporating Choice Into an Attitudinal Framework: Analyzing Models of Mental Comparison Processes., Journal of Consumer Research 21 (June), p. 100-118.

Dabholkar, P. A. (1996): Consumer evaluations of new technology-based self-service options: An investigation of alternative models of service quality. International Journal of Research in Marketing, 13 (1), p. 29-51.

Dabholkar, P. A. - Bagozzi, P. R. (2002): An attitutional model of technology-based self-service: Moderating effects of consumer traits and situational factors. Journal of Academy of Marketing Science, 30 (3), p. 184-201.

Davis, L. D. - Bagozzi, R. P. - Warshaw, P. R. (1989): User acceptance of computer technology: A comparison of two theoretical models. Management Science, 35 (8), p. 982-1003.

De Ruyter, K. - Wetzels, M. - Kleijnen, M. (2001): Customer adoption of e-service: an experimental study. International Journal of Service Industry Management, 12(2), p. 184-207.

Fenigstein, A. - Scheier, M. F. - Buss, A. H. (1975): Public and private self-consciousness: Assessment and theory. Journal of Consulting and Clinical Psychology, 43(4), p. 522.

Gelbrich, K. - Sattler, B. (2014): Anxiety, crowding, and time pressure in public self-service technology acceptance. Journal of Services Marketing, 28(1), p. 82-94.

Hui, M. K. - Bateson, J. E. (1991): Perceived control and the effects of crowding and consumer choice on the service experience. Journal of Consumer Research, 18(2), p. 174-184.

Johnson, D. S. (2007): Achieving customer value from electronic channels through identity commitment, calculative commitment, and trust in technology. Journal of Interactive Marketing, 21(4), p. 2-22.

Johnson, D. S. - Bardhi, F. - Dunn, D. T. (2008): Understanding how technology paradoxes affect customer satisfaction with self service technology: The role of performance ambiguity and trust in technology. Psychology \& Marketing, 25(5), p. 416-443.

Kelly, P. - Lawlor, J. - Mulvey, M. (2013): Customer decisionmaking processes and motives for self-service technology usage in multi-channel hospitality environments. International Journal of Electronic Customer Relationship Management, 7(2), p. 98-116.

Kenesei, Zs. - Janecskó, E. (2015): Önkiszolgáló technológiák elfogadásának vizsgálata a szerepelmélet segítségével. Vezetéstudomány, 46 (1), p. 2-19.
Keszey, T. (2018): Bizalom és vezetői információ-felhasználás: a hatalom moderáló hatása. Statisztikai Szemle, 96 (2), p. 161-184.

Keszey, T. - Zsukk, J. (2017): Az új technológiák fogyasztói elfogadása a magyar és nemzetközi szakirodalom áttekintése és kritikai értékelése. Vezetéstudomány, 48(10), p. 38-47.

Kokkinou, A. - Cranage, D. A. (2013): Using self-service technology to reduce customer waiting times. International Journal of Hospitality Management, 33, p. 435-445.

Langer, E. J. - Saegert, S. (1977): Crowding and cognitive control. Journal of Personality and Social Psychology, 35(3), p. 175.

Limayem, M. - Hirt, S. G. - Cheung, C. M. (2007): How habit limits the predictive power of intention: The case of information systems continuance. MIS Quarterly, p. 705-737.

Liu, S. (2012): The impact of forced use on customer adoption of self-service technologies. Computers in Human Behavior, 28(4), p. 1194-1201.

Liljander, V. - Gillberg, F. - Gummerus, J.- Van Riel, A. (2006): Technology readiness and the evaluation and adoption of self-service technologies. Journal of Retailing and Consumer Services, 13, p. 177-191.

Lin, J. S. C. - Hsieh, P. L. (2007): The influence of technology readiness on satisfaction and behavioral intentions toward self-service technologies. Computers in Human Behavior, 23(3), p. 1597-1615.

Meuter, M. L. - Ostrom, A. L. - Bitner, M. J. - Roundtree, R. (2003): The influence of technology anxiety on consumer use and experiences with self-service technologies. Journal of Business Research, Vol. 56, p. 899-906.

Oh, H. - Jeong, M. - Baloglu, S. (2013): Tourists' adoption of self-service technologies at resort hotels. Journal of Business Research, 66(6), p. 692-699.

Reinders, M. J. - Dabholkar, P. A. - Framback, R. T. (2008): Consequences of forcing consumers to use technology-based self-service. Journal of Service Research, 11(2), p. 107-123.

Reinders, M. J. - Frambach, R. - Kleijnen, M. (2015): Mandatory use of technology-based self-service: does expertise help or hurt? European Journal of Marketing, 49(1/2), p. 190-211.

Scherer, A. - Wünderlich, N. - Von Wangenheim, F. (2015): The Value of Self-Service: Long-Term Effects of Technology-Based Self-Service Usage on Customer Retention. MIS Quarterly, 39(1), p. 177-200.

Trampe, D. - Konuş, U. - Verhoef, P. C. (2014): Customer responses to channel migration strategies toward the e-channel. Journal of Interactive Marketing, 28(4), p. 257-270

Van Beuningen, J. - De Ruyter, K. - Wetzels, M. - Streukens, $S$. (2009): Customer self-efficacy in technology-based self-service: assessing between-and within-person differences. Journal of Service Research, 11(4), p. 407-428.

Walker, R. H. - Johnson, L.W. (2006): Why consumers use and do not use technology-enabled services. Journal of Services Marketing, Vol. 20 No. 2, p. 125-135.

Webster, J. - Martocchio, J. J. (1992): Microcomputer playfulness: Development of a measure with workplace implications. MIS Quarterly, p. 201-226.

Zhao, X. - Mattila, A. S. - Eva Tao, L. S. (2008): The role of post-training self-efficacy in customers' use of self service technologies. International Journal of Service Industry Management, 19(4), p. 492-50 